\title{
Service Delivery and Customer Satisfaction in the Public Service Sector:An Ethiopian Experience
}

\author{
Alemseged Gerezgiher Hailu \\ Center for Rural Development, Addis Ababa University \\ Hailay Gebretsadik Shifare \\ Ethiopian Management Institute, P.O.Box 26205, Addis Ababa, Ethiopia
}

\begin{abstract}
The purpose of the study is to assess the existing service delivery and customer satisfaction of selected federal ministries/organizations in Ethiopia. The data collecting instruments employed in the study were questionnaires and key informant interview guides. Primary data was collected using self-administered, structured questionnaire from respondents (165 employees and 423 customers). The data obtained from the above sources were organized, presented and analyzed by using both qualitative and quantitative methods of research analysis. The result shows customers of public service organizations perceived positively that they are satisfied by the overall service delivery of the organizations. However, there were service delivery differences within different sections of every selected public service organizations and among each selected organization, which is statistically significant. The main challenges of public service delivery were lack of accountability, willingness to provide service as per request, sense of belongingness, inconsistencies of rules and regulations, and lack of integration problem among different government service providers. The public service organizations should introduce appropriate and realistic accountability measures; and work together in preparation of their rules, regulations, and procedure consistently so that they would have better integration, which enable them to provide good service delivery to their customers.
\end{abstract}

Keywords: Public service, Service delivery, SERVQUAL, Customer satisfaction, Ethiopia

DOI: $10.7176 /$ PPAR/9-9-04

Publication date:September $30^{\text {th }} 2019$

\section{Introduction}

The service industry plays a great and important role in the economy of countries in the world. In the $21^{\text {st }}$ century, which is characterized by high competition and business dynamism among others, providing quality service to customers is considered as essential strategy for survival and sustainable growth (Vijayakanth et al., 2014). In the global world, providing quality service is crucial for the accomplishment and continuous existence (Parasuraman et al., 1985; Reichhld \& Sasser, 1990; Zeithaml et al., 1990). All over the world, public service institutions have responsibility for providing sufficient service to clients/citizens as per their request (Benjamin, 2012). The public sector has responsibility and accountability for delivering efficient and effective services to communities and societies as a customer. Though public service institutions, now days, have an ever-increasing demands to deliver best services and improve efficiency relatively compared to previous times, demands are changing in their quality requirements in government and private sector.

Despite the fact that the incumbent Ethiopian Government introduced different reform programs to increase service delivery and customer satisfaction, there are many challenges and problems in the public sector. Several research studies on the issue indicated that the service performance of the sectors is not up to the satisfaction level of the public (Emnet \& Habtamu, 2011), poor integration and sequential approach (Mesfin, 2009). Thus, the purpose of the study is to assess service quality and customers' satisfaction in public sector selected federal organizations in Ethiopia.

Service quality is an overall result similar to attitude towards the service and generally accepted as a predecessor of overall customer satisfaction (Zeithaml \& Bitner, 1996). Customers are the corner stone's of service provider in that without customer it is difficult to assure sustainable continuity and growth of organizations. Hence, the Ethiopian public service organizations have the responsibility to provide efficient service to clients and achieve the goals of their mission. To this end, government has been introducing various reforms to bring about a remarkable change that ensures expectations of the customers. For this very reason, public sector organizations put boldly the services they provided and express their willingness to implement effective and efficient service practically on the ground. It is vividly observed that there are complains in service provision and the satisfaction of customers when looking it vis-à-vis the status of service provision by organizations and perceptions' of customers (Emnet \& Habtamu, 2011).

Many studies have been done in relation to this topic; For example, a descriptive study conducted by Fariba Azizzadeb, Kahalili, Iraj Soltani (2013) on service quality measurement in the public sector using SERVQUAL model have found that there is a difference between customer expectation and present service delivery in terms 
of tangibility, reliability, empathy and guarantee. Similarly, Ilhaamie (2010) has also studied the quality of service provision in Malaysian public sector and expectation of external customers using SERVQUAL instrument. The result shows that the overall service delivery was good in the public sector however, this study focused only the external customer side without including the internal customers/employee side/.

Furthermore, a survey study on the comparison of private and public service organizations in terms of customer Satisfaction through Service Quality across Karnataka (India) was done with specific focus on the investigation of how closely customer expectations of service and front line employees' perceptions of customer expectations match. The result of this survey indicated that employees and customers do not have significant differences in opinions in terms of the gaps between their perceptions and expectations of government and private organization (Urs, Harirao \& Kumar, 2014).

However, the literature tells us that the studies done on the subject of service quality and customer satisfaction appear to be mostly focusing on private sector. Nevertheless, if we take the context of developing countries like Ghana the public sectors is mainly the dominant player in service delivery (Benjamin, 2012) which requires research attention and the context of Ethiopia is not different from this fact.

In Ethiopia different studies have been done on customer satisfaction in the public organizations (e.g. A survey on the assessment of customer satisfaction on Ethiopian Telecom (Potluri \& Mangnale, 2010), A research note on Clients and clinician satisfaction with laboratory services at selected government hospitals in eastern Ethiopia (Zelalem Teklemariam, Abiyu Mekonnen, Haji Kedir and Getachew Kabew, 2013).

Therefore, the conceptual challenges identified in this research are bad record track and pick-drop culture of reform tools, the top-down approach or lack of adequate consultation of stakeholders and lack of implementation capacity. However, the assessment of service quality and customers' satisfaction on the specified federal organizations is not yet studied.

A research conducted by Jenet (2011) with a methodology SERVQUAL MODEL come up with the idea that service quality and customer satisfaction are different in their dimensions. However, the study was unable to incorporate views of employees while they are providing service to their customers. Hence, the here researchers are interested to address; has the service delivery in the selected organizations in Ethiopia lived up to the customers' satisfaction in respect of bringing about predicted quality services? How about the employees? Do they know clearly whether the services they provide are as per quality or not? Therefore, this research focuses on service quality and customers' satisfaction in the selected governmental organizations in Ethiopia.

\section{Research Objectives}

The general objective of the paper is to assess service quality and customers' satisfaction of public sector in selected governmental ministry/institution/office of Ethiopia.

Specific Objectives

1. To describe service delivery status in the public service sector of Ethiopia.

2. To investigate the determinants of customer satisfaction in the selected public service organizations.

3. To identify the challenges of selected public service delivery in public service sector of Ethiopia.

\section{Service Delivery and Customer Satisfaction: a Nexus}

Customers are the corner stone of any organization. And, therefore, customer satisfaction remains at the heart of the decisions and actions of organizations of all type. Parasuraman et al. (1985) conceptualized service excellence as the gap between customers' hope and their awareness of the service practice. Based on their conceptualization of service quality, an instrument of measuring customer satisfaction against service delivery was developed basically for private organizations. The instrument is commonly called as service quality (SERVQUAL) and has five dimensions (Nyeck et al., 2002). These are tangibility, reliability, responsiveness, assurance, and empathy (van Iwaarden et al., 2003). Specifically, public sector organizations, especially in developing countries, face particular difficulties in measuring service quality.

This is so because the tradition of measuring customer satisfaction against service delivery was confined to private organizations long time now. However, in recent times clients of public service organizations demand for prompt and quality service has significantly grown. This is an issue of worry to the public since they are the taxpayers, and it is their taxes that are used to finance these public sector organizations, and therefore, they expect that good services are provided to clients in return (Abdullah, 2006). Likewise, revenue is not the last purpose of these public organizations as they play unlike responsibility such as catalyst, pacemaker and socioeconomic developer (Arawati, Barker and Kandampully, 2007). Thus, in an attempt to solve their difficulties scholars to adopt models developed in the private sector to the public service sector. Such models try to link service delivery and quality with customer satisfaction (Parasuraman et al. 1985, 1988, and 1994). For example, some notable researchers such as Iihaamie (2010) studied service quality as an important dimension of organizational performance in the public sector. 
As the main output of most public sector organizations is service delivery, Brysland and Curry (2001) stated that the literature clearly supported the use of SERVQUAL in the public sector. And, Gowan et al. (2001), highlighted that service provision is more complex in the public sector because it is not simply a matter of meeting expressed needs, but of finding out unexpressed needs, setting priorities, allocating resources and publicly justifying and accounting for what has been done) were undertaken in the public service sector and they establish the relationship between service delivery and customer satisfaction.

To this end, the conceptual framework and hypotheses to analyze the nexus between service delivery and customer satisfaction in the public service sector of Ethiopia are depicted below.

\section{Service Quality}

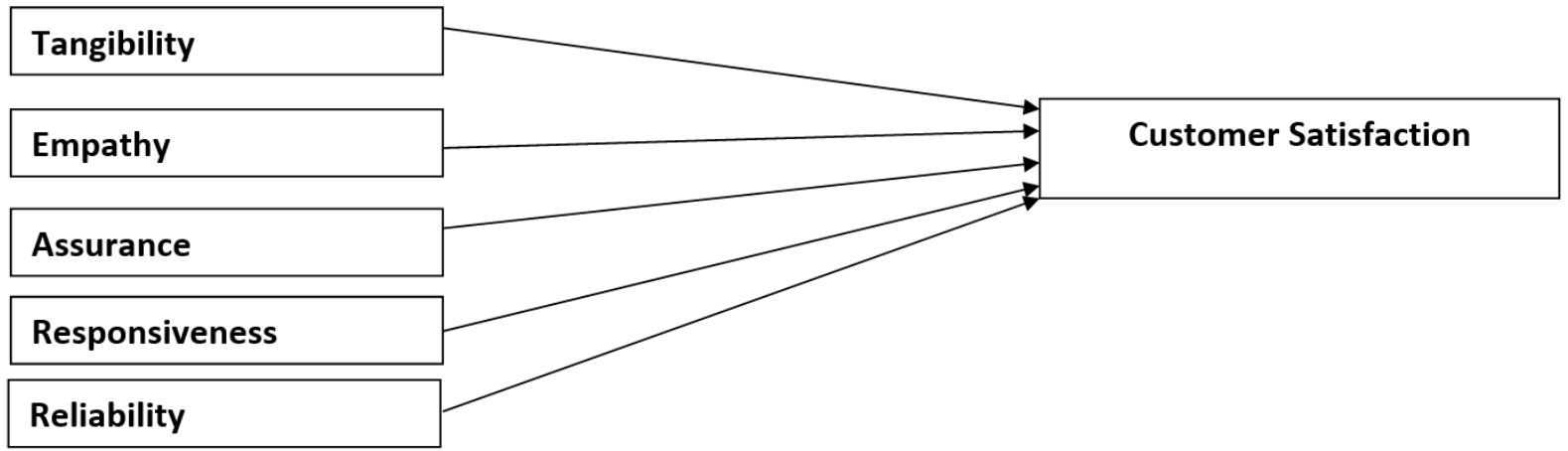

Source: Institute of Interdisciplinary Business Research (2010)

The following hypotheses are set based on the above conceptual review and are tested in the results and discussions part.

H1: Service quality dimensions do affect customer satisfaction in the public service institutions.

H1: Service providing employees characteristics do affect customer satisfaction in the public service institutions. H1: The type and characteristics of the public service institution affects customer satisfaction.

\section{Research Methodology}

\section{Description of the study area}

The study area, Addis Ababa-Ethiopia, was purposively selected as it fits for the purpose of the study. This is so because Addis Ababa is the capital city and seat of all Federal ministries and/or institutions in Ethiopia. Among the various public service organizations, DARO, EMI, MoGCA and MoCT were selected for the study. The institutions/ministries were selected purposely through the following criteria.

One is capacity-building, communication/PR, great /opportunity/ concern for the country, has more customers with different background. Hence, EMI is engaged in capacity building and it has more than 264 Federal and Regional clients. DARO is also a Federal Document Authentication and Registration Agency and has more than 1 million customers each year. MoCT is a Ministry of Culture and Tourism and the country give due attention to exploit its tourism resources and benefited from the industry by establishing tourism transformation council lead by prime minister. MoGCA- is government communications affair office served as a bridge between the government and peoples at large.

\section{Research Design and Strategy}

This research employ a mixed methodology as it uses both qualitative and quantitative data. As Creswell (2003) stated, using only qualitative or quantitative research methodology has its own limitations.

However, mixed methods make the research process \& its findings more valuable by offsetting the limitation of each research approach. Therefore, the researcher applied a mix of descriptive and exploratory survey research design and mixed methodology in data collection in order to answer the gap identified in the research process.

\section{Data Type and Sources}

The researcher used both qualitative and quantitative data types. Both primary and secondary source of data were employed. The primary sources of data were collected from users, administrators and key informants of five federal ministries/organizations DARO, EMI, MoGCA and MoCT.

Secondary source of data were collected from relevant sources such as report of the institutions/ministries, organizations' citizens' charter and document review of all the selected ministries report and customers' suggestions boxes.

\section{Sample Design}

The target population of the study consists of customers and employees of four selected federal ministries/institutions, DARO, EMI, MoGCA and MoCT and these organizations are the unit of analysis. 


\section{Sample Size Determination}

The researchers employed proportional purposive sampling method. i.e., proportional selections of respondents were made with respective of size of each sampling units in the study area. The benefits of using this process includes representativeness with respect to variables used as the basis of categorizing and increased chances of being able to make comparisons between the units. Lack of information on proportion of the population in each category and faulty classification may be listed as disadvantages of this method. The sampling size determination formula for employees is derived from. Kothari stated that in case of finite population the sampling size determination formula is as follows;

Where,

$$
\mathrm{n}=\mathrm{e}^{2} \cdot \frac{\mathrm{z}^{2} \cdot \mathrm{p} \cdot \mathrm{q} \cdot \mathrm{N}}{(\mathrm{N}-1)+\mathrm{z}^{2} \cdot p \cdot q}
$$

$N=$ size of population

$n=$ size of sample

$e=$ acceptable error

$p=$ sample proportion of successes, $q=1-p$;

$z=$ the value of the standard variate at a given confidence level

The size of the total population is around 985 where $\mathrm{p}$ is 0.5 because at this $\mathrm{p}$ value $n$ was the maximum and the sample yield at least the desired precision.

The $\mathrm{z}$ value at $95 \%$ of confidence level is 1.96 .

$$
\text { Sample }=\quad(0.05)^{2} \cdot \frac{(1.96)^{2} \cdot(0.5)(0.5) \cdot 945.99}{(985-1)+(1.96)^{2} \cdot(0.5)(0.5)}
$$

Therefore, sample size $=\underline{\mathbf{2 7 6}}$

Table 1: Proportional Allocation

\begin{tabular}{|l|l|c|c|c|}
\hline S.N. & \multicolumn{1}{|c|}{ Name of organization } & NO. Employee & $\begin{array}{c}\text { Proportional } \\
\text { allocation }\end{array}$ & $\begin{array}{c}\text { Sample } \\
\text { size }\end{array}$ \\
\hline 2 & $\begin{array}{l}\text { Document Authentication and Registration } \\
\text { Agency }\end{array}$ & 150 & 0.15 & 24 \\
\hline 3 & Ethiopian Management Institute & 281 & 0.27 & 79 \\
\hline 4 & Ministry of Culture and Tourism & 326 & 0.33 & 113 \\
\hline 5 & $\begin{array}{l}\text { Ministry of Government Communication } \\
\text { Affairs }\end{array}$ & 228 & 0.25 & 60 \\
\hline
\end{tabular}

Source: Data collected from the study organizations, 2017

Therefore, the sample size of the population is 276 .

Data were collected from the selected civil service organizations according to the given formula. Consequently, 276 questionnaires were distributed to employees and 165 were collected. Furthermore, there was also one focus group discussion for each institutions/ministries citizen's wing representatives.

Table 2: Proportional Allocation

\begin{tabular}{|l|l|c|c|c|}
\hline S.N. & \multicolumn{1}{|c|}{ Name of organization } & NO. customers & $\begin{array}{c}\text { Proportional } \\
\text { allocation }\end{array}$ & $\begin{array}{c}\text { Sample } \\
\text { size }\end{array}$ \\
\hline 1 & $\begin{array}{l}\text { Document Authentication and Registration } \\
\text { Agency }\end{array}$ & $1,297,169$ & 0.70 & 385 \\
\hline 2 & Ethiopian Management Institute & 261 & 0.08 & 44 \\
\hline 3 & Ministry of Culture and Tourism & 60 & 0.02 & 11 \\
\hline 4 & $\begin{array}{l}\text { Ministry of Government Communication } \\
\text { Affairs }\end{array}$ & 175 & 0.05 & 28 \\
\hline
\end{tabular}

Source: Data collected from the study organizations, 2017

Many literatures (Andrian Furnham, K.V.Petrides, Chris J.Jackson, Tim Cotter, 1999) confirm that if the number of total population is greater than 100,000, it is recommended to take 383 samples. But to be more representative the researchers took 500 samples.

\section{Data Collection and Instrument}

In order to know the overall picture of the customer satisfaction and service quality of the selected federal ministries/institutions which was included in the study area as mentioned earlier, primary data was collected using SERVQUAL questionnaire and interview and focus group discussion.

Open-ended and close-ended questionnaire were used for the selected four institutions/ministries customers. Because the purpose of descriptive survey is gathering the respondent's answer using descriptive method concluding about large population by taking representative sample, (Leedy \& Ormrod, 2005).

Close-ended questionnaire was applied to understand how the institutions provide services as per the 
interest of customers, information regarding conducive environment and system in service provision, awareness of civil servant in providing quality service, how they treat customers, expectations of customers. The researcher preferred this technique, because close-ended questionnaires require less time, and are easier for the respondent to answer.

In order to triangulate the data collected through questionnaire, the researchers were also utilized tools such as interview for clients and employees of the selected institutions' customer service and focus groups for customers in each organization.

The time of data collection and conducting the study were about three months, and four enumerators (who are first-degree holders) and the researcher himself did this. Before the data collections were made, one-day training was given to the enumerators about the objectives of the study. In addition, before the full-fledge study is underway; a pilot study was carried out by the researcher on few selected ministries/institutions.

After the pilot study, some necessary adjustments were made to the questionnaire to accommodate the loopholes identified during the pilot study.

The interview questions were analysed and processed using the qualitative method. The analysis part was focusing on five SERVQUAL model such as reliability, responsiveness, tangibles, empathy, assurance. Since gaps are created when the perception of the delivered service is not as per the expectations of the customers and therefore it is crucially vital to probe this gap with respect to factors affecting satisfaction of customers.

Data Processing and Analysis

The collected data were analysed using quantitative and qualitative approach and entered into spreadsheet SPSS software version 20. The close-ended questions were analysed quantitatively that is by using descriptive statistics, inferential statistics and regression models. Descriptive statistics such as frequencies and percentages, mean, standard deviation and range were used to run univariate analysis on each main variable. Furthermore, inferential statistics like correlations, chi-square, two-sample t-test, one way ANOVA, are used to identify associations, differences and significances of these associations and differences. Importantly, linear regression was employed to investigate determinants of service quality and customer satisfaction.

\section{Results and Discussions}

\subsection{Pre- Analysis test}

In order to know the overall picture of the customer satisfaction and service quality of the selected federal ministries, institutions and offices which are included in the study area as mentioned earlier, primary data was collected using SERVQUAL questionnaire and interview and focus group discussion. Therefore, before the full data collection takes place, the researchers conduct pre-test to assure the reliability and validity of the instruments.

Validity: refers to the problem of whether the data collected reflects the true picture of what is being studied. So regarding the service delivery and customer satisfaction the collected data from customers, employees, and secondary data from the organizations tells sound solution for the problem.

Table 3: Over all Expectation

\begin{tabular}{|l|r|r|r|}
\hline \multirow{2}{*}{ Construct } & \multicolumn{3}{|c|}{ Reliability Statistics of SERVQUA Dimensions for Expectations } \\
\cline { 2 - 4 } & No. of Items & Cronbach's Alpha & $\begin{array}{c}\text { Cronbach's Alpha Based on Standardized } \\
\text { Items }\end{array}$ \\
\hline Tangibles & 4 & .752 & .768 \\
\hline Reliability & 5 & .832 & .831 \\
\hline Responsiveness & 4 & .661 & .696 \\
\hline Assurance & 4 & .531 & .620 \\
\hline Empathy & 5 & .573 & .664 \\
\hline \multicolumn{2}{|r|}{} & Overall & $\mathbf{0 . 6 1 5}$ \\
\hline
\end{tabular}

Source: Own Survey, 2017

The reliability of overall expectation consists of 22 scale items is 0.615 . So in reliability test if Cronbach's Alpha result lies 0.6-0.89, it is accepted. Therefore, our instrument is reliable. 
Table 4: Over all Perception

\begin{tabular}{|l|l|l|l|}
\hline \multirow{2}{*}{ Construct } & \multicolumn{2}{|c|}{ Reliability Statistics of SERVQUAL Dimensions for Perceptions } \\
\cline { 2 - 4 } & No. of Items & Cronbach's Alpha & \multicolumn{1}{c|}{$\begin{array}{c}\text { Cronbach's Alpha Based on Standardized } \\
\text { Items }\end{array}$} \\
\hline Tangibles & 4 & .686 & .683 \\
\hline Reliability & 5 & .787 & .779 \\
\hline Responsiveness & 4 & .844 & .844 \\
\hline Assurance & 4 & .678 & .717 \\
\hline Empathy & 5 & .848 & .851 \\
\hline Overall & & $\mathbf{0 . 7 7 4}$ \\
\hline
\end{tabular}

Source: Own Survey, 2017

The reliability of overall expectation consists of 22 scale items is $\mathbf{0 . 7 7 4}$. So in reliability test if Cronbach's Alpha result lies 0.6-0.89, it is accepted. Therefore, our instrument is reliable.

Table 5: General Biography of Customer Respondents

\begin{tabular}{|c|c|c|c|c|c|c|c|c|c|c|}
\hline & \multicolumn{8}{|c|}{ Organization Name } & \multirow[b]{2}{*}{ Total } \\
\hline & & \multicolumn{2}{|r|}{ EMI } & \multicolumn{2}{|r|}{ DARO } & \multicolumn{2}{|r|}{ MoCT } & \multicolumn{2}{|c|}{ MoGCA } & \\
\hline & & & Column & \multicolumn{2}{|c|}{$\%$ Count Column } & \multicolumn{2}{|c|}{ \% Count Column } & \multicolumn{2}{|c|}{$\%$ Count Column } & \\
\hline \multirow{3}{*}{ Sex 1} & Male & 19 & 48.7 & 264 & 75.0 & 2 & 33.3 & 19 & 95.0 & 304 \\
\hline & Female & 20 & 51.3 & 88 & 25.0 & 4 & 66.7 & 1 & 5.0 & 113 \\
\hline & Total & 39 & 100 & 352 & 100 & 6 & 100 & 20 & 100 & \\
\hline \multirow{6}{*}{ Age2 } & $18-25$ & 11 & 27.5 & 65 & 18.5 & 1 & 16.7 & 1 & 4.5 & 78 \\
\hline & $26-33$ & 11 & 27.5 & 158 & 44.9 & 5 & 83.3 & 4 & 18.2 & 178 \\
\hline & $34-41$ & 10 & 25.0 & 89 & 25.3 & 0 & 0.0 & 13 & 59.1 & 112 \\
\hline & $42-49$ & 7 & 17.5 & 31 & 8.8 & 0 & 0.0 & 4 & 18.2 & 42 \\
\hline & $>=50$ & 1 & 2.5 & 9 & 2.6 & 0 & 0.0 & 0 & 0.0 & 15.1 \\
\hline & Total & 40 & 100 & 352 & 100 & 6 & 100 & 22 & 100 & \\
\hline \multirow{5}{*}{$\begin{array}{c}\text { Educational } \\
\text { Level }\end{array}$} & Read and write & 0 & 0.0 & 0 & 0.0 & 0 & 0.0 & 0 & 0.0 & 0 \\
\hline & $\begin{array}{c}\text { Elementary school } \\
\text { complete }\end{array}$ & 0 & 0.0 & 24 & 6.6 & 1 & 14.3 & 2 & 9.1 & 57 \\
\hline & Secondary school & 4 & 9.5 & 133 & 36.6 & 1 & 14.3 & 3 & 13.6 & 141 \\
\hline & 1st Degree and Above & 38 & 90.5 & 206 & 56.7 & 5 & 71.4 & 17 & 77.3 & 266 \\
\hline & Total & 42 & 100 & 363 & 100 & 7 & 100 & 22 & 100 & \\
\hline \multirow{7}{*}{ Job } & Jobless & 0 & 0.0 & 17 & 4.8 & 0 & 0.0 & 0 & 0.0 & 17 \\
\hline & Private job & 0 & 0.0 & 193 & 54.8 & 3 & 42.9 & 0 & 0.0 & 196 \\
\hline & Civil servant & 42 & 100.0 & 74 & 21.0 & 0 & 0.0 & 21 & 95.5 & 137 \\
\hline & $\begin{array}{c}\text { Private organization } \\
\text { employee }\end{array}$ & 0 & 0.0 & 60 & 17.0 & 4 & 57.1 & 1 & 4.5 & 65 \\
\hline & NGO employee & 0 & 0.0 & 6 & 1.7 & 0 & 0.0 & 0 & 0.0 & 6 \\
\hline & Retired & 0 & 0.0 & 2 & 0.6 & 0 & 0.0 & 0 & 0.0 & 2 \\
\hline & Total & 42 & 100 & 352 & 100 & 7 & 100 & 22 & 100 & \\
\hline
\end{tabular}

Source: Own Survey, 2017

The above table 5.3 shows that profile of the respondents participated in this study are customers' of EMI (48.7\%), DARO (75\%), MoCT (33.3\%), and MoGCA (95\%) respectively. Moreover, the participation of males in DARO and MoCGA is high. On the other hand, female respondents are EMI (51.3\%), DARO (25\%), MoCT $(66.7 \%)$, and MoGCA (5\%) respectively. Therefore, this implies the actual workplace females participation in EMI and MoCT is high.

Furthermore, with regard to respondents job profile, EMI customers are almost all civil servants where as DARO's customers are from different job categories. Hence, this study's coverage is all-inclusive customers (civil servants, any ordinary citizens, different educational background, and varied age group). 
Table 6: General Biography of Employee Respondents

\begin{tabular}{|c|c|c|c|c|c|c|c|c|c|}
\hline & & & & & & \multicolumn{4}{|c|}{ Organization Name } \\
\hline & & & & & & EMI & DARO & MoCT & MoGCA \\
\hline & & & & & & Count & Count & Count & Count \\
\hline \multirow{24}{*}{$\begin{array}{l}\text { Monthly } \\
\text { Income }\end{array}$} & \multirow{8}{*}{$\begin{array}{l}601- \\
3200\end{array}$} & \multirow{8}{*}{$\begin{array}{l}\text { Educational } \\
\text { Level }\end{array}$} & \multirow{2}{*}{$\begin{array}{l}\text { Read and } \\
\text { write }\end{array}$} & \multirow[t]{2}{*}{ Sex } & Male & 0 & 0 & 0 & 0 \\
\hline & & & & & Female & 0 & 0 & 0 & 0 \\
\hline & & & \multirow{2}{*}{$\begin{array}{l}\text { Elementary } \\
\text { school } \\
\text { complete }\end{array}$} & \multirow[t]{2}{*}{ Sex } & Male & 0 & 0 & 1 & 0 \\
\hline & & & & & Female & 2 & 3 & 0 & 0 \\
\hline & & & \multirow{2}{*}{$\begin{array}{l}\text { Secondary } \\
\text { school }\end{array}$} & \multirow[t]{2}{*}{ Sex } & Male & 4 & 0 & 1 & 5 \\
\hline & & & & & Female & 5 & 1 & 6 & 0 \\
\hline & & & \multirow{2}{*}{$\begin{array}{l}\text { 1st Degree } \\
\text { and Above }\end{array}$} & \multirow[t]{2}{*}{ Sex } & Male & 2 & 1 & 6 & 4 \\
\hline & & & & & Female & 1 & 4 & 5 & 1 \\
\hline & \multirow{8}{*}{$\begin{array}{l}3201- \\
7800\end{array}$} & \multirow{8}{*}{$\begin{array}{l}\text { Educational } \\
\text { Level }\end{array}$} & \multirow{2}{*}{$\begin{array}{l}\text { Read and } \\
\text { write }\end{array}$} & \multirow[t]{2}{*}{ Sex } & Male & 0 & 0 & 0 & 0 \\
\hline & & & & & Female & 0 & 0 & 0 & 0 \\
\hline & & & \multirow{2}{*}{$\begin{array}{l}\text { Elementary } \\
\text { school } \\
\text { complete }\end{array}$} & \multirow[t]{2}{*}{ Sex } & Male & 0 & 2 & 0 & 0 \\
\hline & & & & & Female & 0 & 1 & 0 & 0 \\
\hline & & & \multirow{2}{*}{$\begin{array}{l}\text { Secondary } \\
\text { school }\end{array}$} & \multirow[t]{2}{*}{ Sex } & Male & 5 & 2 & 2 & 1 \\
\hline & & & & & Female & 7 & 1 & 5 & 1 \\
\hline & & & \multirow{2}{*}{$\begin{array}{l}\text { 1st Degree } \\
\text { and Above }\end{array}$} & \multirow[t]{2}{*}{ Sex } & Male & 18 & 7 & 8 & 24 \\
\hline & & & & & Female & 10 & 6 & 11 & 4 \\
\hline & \multirow{8}{*}{$\begin{array}{l}78001- \\
10900\end{array}$} & \multirow{8}{*}{$\begin{array}{l}\text { Educational } \\
\text { Level }\end{array}$} & \multirow{2}{*}{$\begin{array}{l}\text { Read and } \\
\text { write }\end{array}$} & \multirow[t]{2}{*}{ Sex } & Male & 0 & 0 & 0 & 0 \\
\hline & & & & & Female & 0 & 0 & 0 & 0 \\
\hline & & & \multirow{2}{*}{$\begin{array}{l}\text { Elementary } \\
\text { school } \\
\text { complete }\end{array}$} & \multirow[t]{2}{*}{ Sex } & Male & 0 & 0 & 0 & 0 \\
\hline & & & & & Female & 0 & 0 & 0 & 0 \\
\hline & & & \multirow{2}{*}{$\begin{array}{l}\text { Secondary } \\
\text { school }\end{array}$} & \multirow[t]{2}{*}{ Sex } & Male & 0 & 0 & 0 & 0 \\
\hline & & & & & Female & 0 & 0 & 0 & 0 \\
\hline & & & 1st Degree & Sex & Male & 0 & 0 & 0 & 0 \\
\hline & & & and Above & & Female & 0 & 0 & 0 & 0 \\
\hline & & & & & Total & 54 & 28 & 45 & 38 \\
\hline
\end{tabular}

Source: Own Survey, 2017

The above table 5.4 indicates that majority of employees of the civil service organizations educational background is $1^{\text {st }}$ degree and their salary lies in the range of 3,200-7,800 birr. In addition, employees of the civil service organizations either are educated by themselves or support of their organizations.

Table 7: Biography of Respondents: Statistical Difference in Sex, Age, Educational Level And Job

\begin{tabular}{|l|l|r|}
\hline \multicolumn{2}{|c|}{ Pearson Chi-Square Tests } & Organization Name \\
\hline \multirow{3}{*}{ Sex1 } & Chi-square & 22.030 \\
\cline { 2 - 3 } & Df & 3 \\
\cline { 2 - 3 } & Sig. & $.000^{*}, \mathrm{~b}$ \\
\hline \multirow{3}{*}{ Age2 } & Chi-square & 28.193 \\
\cline { 2 - 3 } & Df & 12 \\
\cline { 2 - 3 } & Sig. & $.005^{*}, \mathrm{~b}, \mathrm{c}$ \\
\hline \multirow{3}{*}{ Educational Level } & Chi-square & 23.681 \\
\cline { 2 - 3 } & Df & 6 \\
\cline { 2 - 3 } & Sig. & $.001^{*, \mathrm{c}, \mathrm{c}}$ \\
\hline \multirow{3}{*}{ Job } & Chi-square & 159.527 \\
\cline { 2 - 3 } & Df & 15 \\
\cline { 2 - 3 } & Sig. & $.000^{*}, \mathrm{~b}, \mathrm{c}$ \\
\hline
\end{tabular}

Source: Own Survey, 2017

Table 5.5 shows that there is statistically significant difference between/among the selected institutions in terms of gender, age, educational background and job.

\subsection{Service Delivery in the Study Organizations}

Service delivery is more complicated in public institutions because it is not simply meeting expressed needs but 
also finding and satisfying the unexpressed needs (Gowan, 2001). Currently, public service organizations have come under increasing pressure to deliver quality services (Randall and Senior, 1994, and enhanced efficiency (Robinson, 2003). Quality service in public service organizations is slow, and is aggravating by difficulties in measuring outcomes, greater analysis from public and press be deficient in freedom to account in an arbitrary fashion (Teicher et al., 2002).

According to Parasuraman (1985) service quality is the difference between customers' expectation of services and their perceived services.

Table 8: Significant Difference Within and Between Organizations

\begin{tabular}{|c|c|c|c|c|c|c|}
\hline \multicolumn{7}{|c|}{ ANOVA } \\
\hline & & $\begin{array}{l}\text { Sum of } \\
\text { Squares }\end{array}$ & $\mathrm{Df}$ & Mean Square & $\mathrm{F}$ & Sig. \\
\hline \multirow{3}{*}{ Organization } & Between Groups & 13.717 & 21 & .653 & 2.365 & .001 \\
\hline & Within Groups & 113.225 & 410 & .276 & & \\
\hline & Total & 126.942 & 431 & & & \\
\hline \multirow{3}{*}{ Age } & Between Groups & 1166.371 & 21 & 55.541 & 6.917 & .000 \\
\hline & Within Groups & 3019.340 & 376 & 8.030 & & \\
\hline & Total & 4185.711 & 397 & & & \\
\hline \multirow{3}{*}{ Educational Level } & Between Groups & 433.786 & 20 & 21.689 & 2.842 & .000 \\
\hline & Within Groups & 2968.789 & 389 & 7.632 & & \\
\hline & Total & 3402.576 & 409 & & & \\
\hline \multirow{3}{*}{ Job } & Between Groups & 26.335 & 21 & 1.254 & 1.708 & .027 \\
\hline & Within Groups & 277.543 & 378 & .734 & & \\
\hline & Total & 303.878 & 399 & & & \\
\hline
\end{tabular}

Source: Own survey, 2017

Table 5.6 indicates that there is statistically significance difference within organizations (in terms of age, education and job) and between organizations (EMI, DARO, MoClT and MoGCA).

Table 9: SERVQUAL Dimensions (Expectations, Perception and Gap)

\begin{tabular}{|l|l|l|l|l|l|}
\hline \multicolumn{7}{|c|}{ Descriptive Statistics } \\
\hline & N & Minimum & Maximum & Mean & Std. Deviation \\
\hline TangExp & 407 & 1.00 & 5.00 & 3.8342 & .82942 \\
\hline RelibExp & 421 & 1.20 & 5.00 & 4.0285 & .90498 \\
\hline RespExp & 421 & 1.00 & 5.00 & 4.0814 & .85499 \\
\hline AssurExp & 425 & 1.00 & 5.00 & 4.0671 & .82322 \\
\hline EmpaExp & 432 & 1.00 & 5.00 & 3.7995 & .86279 \\
\hline TangPer & 419 & 1.00 & 5.00 & 3.9218 & .81166 \\
\hline ReliaPer & 421 & 1.20 & 5.00 & 4.0285 & .90498 \\
\hline RespPer & 430 & 1.00 & 5.00 & 3.9924 & .86439 \\
\hline AssuPer & 434 & 1.00 & 5.00 & 4.0415 & .86169 \\
\hline EmpatPer & 421 & 1.00 & 5.00 & 3.7306 & .89652 \\
\hline TangGAP & 383 & -2.75 & 3.25 & .0692 & .70161 \\
\hline ReliaGAP & 421 & .00 & .00 & .0000 & .00000 \\
\hline RespGAP & 406 & -2.75 & 3.00 & -.1010 & .66779 \\
\hline AssurGAP & 415 & -2.75 & 1.50 & -.0398 & .65149 \\
\hline EmpathyGAP & 416 & -2.80 & 2.00 & -.0793 & .62937 \\
\hline Valid N (listwise) & 351 & & & & \\
\hline
\end{tabular}

Source: Own survey, 2017

All customers questionnaires response were negative except tangible were positive gap, this indicates that there is a gap between expectation and perception. Therefore, the public service organizations have to work to satisfy the needs of their client/customers. Other studies conducted on similar areas confirms that quality service delivery of public service is not a privileged in a modern society rather it is genuine expectation (Amanfijnr., 2012). Hence, this finding is consistent with the above empirical evidence.

The summary scores for each SERVQUAL dimensions; shown in the above table 5.7, with the average scores per dimension have been totaled to get the overall SERVQUAL score. As you can understand from the above table, responsiveness, empathy and assurance gap have the highest negative score, which means the organizations have little willingness to provide prompt service, poor competency of employees, low understanding to customers, insufficient facilities, and their employees are not capable of doing their assigned task. 
Hence, the current service deliveries of organizations are not compatible with the expected service of the selected public service organizations. So, this result is consistent with Parasuraman (1988) theory about public service organizations and their client's expectation.

However, customers respond negatively/their expectation is greater than their perception/. This implies that the organizations service delivery is low, because result of key informant interview also shows similar poor performance. However, DARO customers respond good service delivery and they were happy. Some of the main justifications were good service delivery, responsive, improved work procedure in its overall service provision.

On the other side, tangible gap have positive value. It was assumed that for this reason, customers have weighted this dimension highest and we can understand that the organizations the necessary facilities and equipment, and personnel and written materials resources are almost the maters of budget. Hence, the government allocates appropriate budget to run the day today operational activity and to provide service to clients.

Service has five distinctive dimensions that were expected by service users (van Iwaarden et al., 2003). The importance of the dimensions varies from sector to sector and even from organization to organization within a sector (Har, 2008). For instance, service quality dimensions expected in banks may not be equally required in public service organizations. Clients' perception of service quality results from a comparison of their beforeservice expectations with their actual service practice.

Service quality was considered as excellent, if perception exceed expectations; it was viewed as adequate, if it only equals the expectations, if it does not meet them, poor (Vazquez et al., 2001). There is also a strong association presented in literature between perceive quality, dedication, devotion, reflection and loyalty (Veloutsou et al.2004).

Hence, the reason behind why responsiveness is highly demanded by the clients; customers need quick response to their request, positive personal attitudes, care about their interest and immediate responsive to their inquiries. Furthermore, the reason behind why assurance is highly demanded by the clients were they give more focus to knowledge and courtesy and service providers ability to inspire trust. Other study conducted by Sriyam (2010), found that assurance dimension demanded high in their expectations whereas tangibility scores high perception.

The reason behind why reliability is highly demanded by the clients is citizens highly need to get service as per promise of the public service organizations. Other studies confirm that reliability is just a matter of keeping word of the organization and delivered as pr its promises (Zeithaml et al., 2006).

Similar to the result on the expected service quality dimensions, the clients perceived high assurance, responsiveness, and reliability. However, the clients relatively respond low result tangible. The low importance of tangibles could be attributable to the fact that customers are aware of the financial constraints which are typical in the public service authority funding context, and simply do not expect much when it comes to aesthetics; instead, they attach more importance to the delivery aspects of the service.

Accordingly, the result of this study indicates that responsiveness, assurance and reliability are the most demanded service quality dimensions in the surveyed public service organizations. Because customers of the selected organizations are highly demand, immediate services to their request, positive and collaborative attitudes of employees, quick service with accuracy. Studies also showed that customers give great concern for speed of response to their complaints(responsiveness), attitudes of staff, employees concern for customers and security for transactions (assurance), speed of services, accuracy of transactions (reliability) (Naik, Gantasala, Prabhakar, 2010).

Generally, the gap between perceived and expected service delivery dimensions, three of them have negative gap in their perceived experience that is lower than expectation of clients. Hence, this implies that customers were not satisfied in the studied public service organizations in responsiveness, assurance and empathy dimensions.

\subsection{Investigating the Determinants of Customer Satisfaction in the Study Organizations}

A discussion on customer satisfaction and customer expectations cannot be complete without discussing the disconfirmation theory. The disconfirmation theory stands out as the primary foundation for satisfaction models in marketing literature (Churchill and Surprenant, 1982; Oliver, 1980). According to this theory, satisfaction is determined by the discrepancy between perceived performance and cognitive standards such as expectations and desires (Khalifa and Liu, 2003). Customer's expectations can be defined as customer's partial beliefs about a product or service (Mckinney et al, 2002).

One service quality measurement model that has been extensively applied is the SERVQUAL model developed by (Parasuraman et al. 1985, 1986). Public service institutions thrive to satisfy their customers (Jenet Manyi Agbor, 2011). For instance, several reforms have been made to improve service delivery and keep their customers satisfied. In this study, customers' satisfactions were measured in terms of six perception 
statements of Likert scale nature.

\section{Table 10: Measuring Customer Satisfaction}

\begin{tabular}{|c|l|l|l|l|l|l|}
\hline S.N & \multicolumn{1}{|c|}{ Perception statements } & M & Min & Max & Mean & $\begin{array}{l}\text { Std. } \\
\text { Deviation }\end{array}$ \\
\hline 1 & I am satisfied with organization's complete range of services & 432 & 1.00 & 5.00 & 4.2778 & .91224 \\
\hline 2 & $\begin{array}{l}\text { I am satisfied with performance of the employee's of the } \\
\text { organization }\end{array}$ & 432 & 1.00 & 5.00 & 4.3380 & .81269 \\
\hline 3 & I am happy being a client of the organization & 432 & 1.00 & 5.00 & 4.3403 & .85487 \\
\hline 4 & $\begin{array}{l}\text { I am satisfied with the organizations employees professional } \\
\text { competency }\end{array}$ & 432 & 1.00 & 5.00 & 4.2176 & .79957 \\
\hline 5 & I am satisfied with the prompt service of the organization & 432 & 1.00 & 5.00 & 4.2894 & .92758 \\
\hline 6 & I am satisfied with the respectful behavior of employees of the & 432 & 1.00 & 5.00 & 4.3241 & .85981 \\
\hline & Organization & Overall Customer Satisfaction 432 & 1.00 & 5.00 & 4.2978 & .73308 \\
\hline
\end{tabular}

Source: Own Survey, 2017

Table 5.8 shows that customer satisfaction of the public organizations; generally, the above result shows that the customers of the selected public service organizations perceived positively they are satisfied by the overall service delivery of organizations. However, the respondents respond that there were service delivery differences within and between the selected public service organizations.

Table 11: ANOVA

\begin{tabular}{|c|c|c|c|c|c|}
\hline \multicolumn{6}{|c|}{ ANOVA } \\
\hline \multicolumn{6}{|c|}{ Measuring customer satisfaction } \\
\hline & Sum of Squares & Df & Mean Square & $\mathrm{F}$ & Sig. \\
\hline Between Groups & 41.865 & 3 & 13.955 & 31.476 & .000 \\
\hline Within Groups & 189.757 & 428 & .443 & & \\
\hline Total & 231.622 & 431 & & & \\
\hline
\end{tabular}

Source: Own Survey, 2017

Measuring customer satisfaction, there is statistically significance difference between public service organizations and within organization. The post hoc test in Annex1 shows that MoGCA customers are less satisfied than EMI, DARO and MoCT. The main reason for the difference were EMI as it is the source of reform tools and change agent institution in federal level, it can relatively practice good change in their job to improve its service delivery.

MoCT and DARO from the recent time have begun to increase their service delivery because of introducing different reform tools. For instance, Ministry of Culture and Tourism has begun to improve its service delivery and achieve its strategic mission push to establish National Tourism Transformation Council lead by prime minister of FDRE; Document Authentication and Registration Agency also introduced best system in service delivery and process in the recent times. MoGCA customers are not satisfied compared to the other organizations. So, MoGCA office is expected to work more to improve its service delivery and to assure that whether customers are satisfied or not. Furthermore, the office should make ready clients waiting room until they get the concerned official. Key informant interview result also confirmed that some of the limitations of the office were insufficient/lack of waiting room of customers and documentation. Hence, the hypothesis that service providing employees' characteristics do affect customer satisfaction in the public service institutions is accepted. 
Table 12: Modeling Determinants of Customer Satisfaction in Public Service Organizations

R Square $=0.511$

Adjusted R Square $=0.496$

$\mathrm{F}(11)=35.083$

P-value $=0.0000$

\begin{tabular}{|c|c|c|c|c|c|}
\hline \multirow[t]{2}{*}{ Variables } & \multicolumn{2}{|c|}{ Unstandardized Coefficients } & \multirow{2}{*}{$\frac{\text { Standardized Coefficients }}{\text { Beta }}$} & \multirow[t]{2}{*}{$\mathbf{T}$} & \multirow[t]{2}{*}{ Sig. } \\
\hline & B & Std. Error & & & \\
\hline (Constant) & $2.144 * * *$ & .196 & & 10.921 & .000 \\
\hline TangExp & -.022 & .055 & -.024 & -.399 & .690 \\
\hline RespExp & $.136^{*}$ & .070 & .156 & 1.939 & .053 \\
\hline AssurExp & -.102 & .072 & -.111 & -1.416 & .158 \\
\hline EmpaExp & $-.124 *$ & .068 & -.142 & -1.804 & .072 \\
\hline TangPer & .063 & .054 & .068 & 1.176 & .241 \\
\hline ReliaPer & -.079 & .065 & -.096 & -1.211 & .227 \\
\hline RespPer & $.326 * * *$ & .066 & .386 & 4.949 & .000 \\
\hline AssuPer & $.225 * * *$ & .067 & .264 & 3.350 & .001 \\
\hline EmpatPer & $.173 * * *$ & .063 & .212 & 2.754 & .006 \\
\hline $\begin{array}{l}\text { Organization } \\
\text { Name }\end{array}$ & $-.105 * *$ & .052 & -.081 & -2.025 & .044 \\
\hline
\end{tabular}

Source: Own Survey, 2017

$* * *, * *$, and $*$ denote significance level at $1 \%, 5 \%$ and $10 \%$ respectively.

Other things being constant, as clients' score on perceived empathy increases by one unit, their satisfaction level increases by 0.173 , statistically significant at $1 \%$. Many researchers have showed a positive relationship between employees' attitudes and customers' perceptions of service quality (Schneider \& Bowen, 1985). Thus, enhancing/improving employees' attitude and empathy towards citizens would be an important strategy for public organizations in order to improve their service provisions.

Keeping other things constant, as clients' score on perceived assurance increases by one unit, their satisfaction level also increases by 0.225 , statistically significant at $1 \%$. Other things being constant, as clients' score on perceived responsiveness increases by one unit, their satisfaction level increases by 0.326 , statistically significant at $1 \%$. Therefore, it can be concluded that, the variables perception empathy, assurance and responsiveness are the most determinant factors in the study organizations. This result is consistent with SERVQUAL explained responsiveness as the willingness to support and give timely service (Parasuraman et al., 1998).

On the expectation side, other things being constant, as clients' score on expected responsiveness increases by one unit, their satisfaction level increases by 0.136 , statistically significant at $1 \%$. Other things being constant, as clients' score on expected empathy decreases by one unit, their satisfaction level decreases by -.124 , statistically significant at $1 \%$.

When we move from EMI to MoGCA, customer satisfaction declines by 0.105 statistically significant at $5 \%$, ceteris paribus.

Therefore, this result is in conformity with eemployees understanding customers' needs and given personal attention to all. However, if there is less concern on understanding customers' view, empathy will decrease accordingly (Institute of Interdisciplinary Business Research, 2010).

\subsection{Challenges of Public Service Delivery}

Public service institutions are the public complaint of long procedures, queues, ineffective service delivery; inconvenience physical facilities affect their image and level of service quality in the sector (Mohammed Nor et al, 2010). Public service organizations in their service delivery, they have many challenges and obstacles. Some of them were customers unable to provide sufficient requirements as per the rules, procedures, and regulations of the organizations. For instance, Document Authentication and Registration Office in its service delivery there are some rules and regulations difference in different countries, but DARO strictly wants to see from its context/Ethiopia/.

However, some customers documents were incomplete, but approved by Ethiopia ministry of foreign affairs and then when they come back to DARO the documents had some limitations/as per DARO detailed and concrete evidence of Ethiopian context/; at this time customers complain to DARO by raising the question "why you provide services as solid as foreign minister?". Furthermore, inconsistency and integration practices were problems in different public service office were also other problems in Ethiopia. Furthermore, divorce regulations in Ethiopia and in foreign countries have significant different, in Ethiopia first you perform divorce and next division of property whereas in foreign countries division of property comes first and divorce next. In 
addition, there are some times problems observed in clients in fulfilling all relevant documents as per the regulations.

This is because of lack of awareness about the service, lack of information. Other studies support the result that is lack of good awareness on service seekers side regarding their responsibilities and obligations (Mesfin \& Taye 2011).

Other challenges of public service delivery were lack of commitment, skilled ready to provide public interest at the right time and situation. On the other hand, customers of the selected public service organizations were sometimes unable to provide the required precondition for service, sufficient documents, and lack of sufficient orientation of the public service organizations services.

Other view of customers were also in other government offices example land administration, Kebele, trade, and revenue authority were highly exposed to corruption, poor service delivery, and rent seeking mentality where as in DARO relatively it were the best government service provider than others.

Another study organization MoGCA key informant interview results also responds that one of the criteria for the customer satisfaction is the service delivery organization can deliver the service efficiently and effectively to the customer per their request. As the respondents response the customers/stakeholders are satisfied through the services but it is moderate satisfaction for the reason that the service provider professionals are not fast enough to transfer customer's application to the one who is in charge for decision-making process on time.

Directive, standard and citizen charter are introduced in the organization but they are not avail for customers. This is the particular issue customers raise regarding to transparency. Other challenge related to handling customer complaints: those customers/stakeholders reported the cause of dissatisfaction. The organization is not responding appropriately according to their work procedures. This situation makes the customer to have feeling of resentment. Beyond that, they also respond there no accountability measure in the office. The other challenges were related to customers caring because the organization does not have waiting room for customers until they get the service. As a result, they do not feel respected. Studies in Ethiopia civil service implementation challenges shows that lack of accountability in performance management system (Solomon, 2007), poor sense of belongingness (Emnet and Habtamu, 2011).

\section{Conclusions and Recommendations Conclusions}

Service delivery and customers' satisfaction status in the public service sectors in terms of the provisions of the service delivery the finding shows that the importance of service quality dimensions in the public service organizations overall SERVQUAL score responsiveness, empathy and assurance gap, have the highest negative score. This implies that the organizations do not provide prompt service, poor competency of employees, low understanding of their customers, and insufficient facilities were among the problems in rendering services by the selected organizations. Reliability and responsiveness relatively have also positive score, which is the organizations employees' ability to perform as per promised and willingness to serve customers is good.

In this study, customers' satisfactions were measured in terms of six perception statements of Likert scale. The result shows that customers of public service organizations perceived positively that they are satisfied by the overall service delivery of organizations. However, there were service delivery differences within different sections of every selected public service organization and among each selected organization, which is statistically significant. There is statistically significance difference between public service organizations and within organization.

EMI, DARO and MoCT customers are relatively satisfied compare to MoGCA office. The main reason for the difference were EMI as it is the source of reform tools and change agent institution in federal level, it can relatively practice good change in their job to improve its service delivery. MoGCA customers are less satisfied than EMI, DARO and MoCT. The reasons behind for this result were lack of accountability, low sense of organizational ownership and insufficient space for customer waiting area.

The main challenges of public service delivery were lack of accountability, willingness to provide service as per request, sense of belongingness. Furthermore, there are also inconsistencies in policies and procedures, lack of integration problem among different government service providers consequently clients unable to get appropriate service and exposes them for confusion.

\section{Recommendations}

The researches' recommendation to increase public service organizations service delivery is that better to work in awareness creation via different mechanism to their clients. Because an aware client helps to clearly ask their rights, consequently the service provider enables them to fill their gap as per the questions and comments of customer.

In a net shell, customer satisfaction of the public organizations shows that customers of public service 
organizations were satisfied. However, this does not mean they are best in all and customers are satisfied. In the key informant interview shows that there are problems with regard lack of accountability, poor willingness to delivery service as per the quality. MoGCA customers are less satisfied than EMI, DARO and MoCT. So the office is expected to give due attention to introduce accountability, provide service effectively and efficiently and prepare sufficient area for customers waiting service. There are also gaps in EMI in providing response to customers as per their request, quality related limitations, and employees dissatisfaction.

Since the institute is capacity builder and highly responsible, it should solve the quality related problems, service responsiveness and employee dissatisfaction by following best international standard, quality measurement, investing more in research and development, and revise its internal work procedure, work load and both financial and non-financial motivational factors and share other similar organizations experiences.

Public service organizations should introduce appropriate and realistic accountability measure, furthermore, there should be more aware to assess their employees satisfaction consequently it helps them immediately to solve any low organizational belongingness. The federal public service organizations also should give due attention for their rules, regulations, and procedure consistency and other integration problems. Hence, it is better to discuss jointly at least the main gaps of the observed problems and give solutions.

\section{References}

Agus, Arawati, Barker, Sunita \& Kandampully, Jay (2007) "an exploratory study of service quality in the Malaysian public service sector," international journal of quality and reliability management, vol. 24(2), p. 177-190.

Andrian Furnham, K.V.Petrides, Chris J.Jackson, Tim Cotter (1999) Do personality factors predict job satisfaction? School of Psychology, University of Queensland, Australia Management Technology Consulting group, Auckland, Newzland.

Amanfi Jnr., Benjamin (2012) Service quality and customer satisfaction in public sector Organizations: a case study of the commission on human rights and Administrative justice.

Brysland, A. \& Curry, A. (2001) "Service Improvements In Public Services Using Servqual," Managing Service Quality, Vol. 11(6), P. 389-401.

Creswell, J. W. (2003). Research design: A qualitative, quantitative, and mixed method approaches (2nd ed.). Thousand Oaks, CA: Sage.

Churchill, Gilbert A. and Carol Surprenant. 1982. "An Investigation In to the Determinants of Satisfaction Research." Journal of Marketing Research 19 (November): 491-504.

Emnet Tadesse And Habtamu Abebachew (2011) Business Process Reengineering Value Handovers In Public Sectors Of Ethiopia: In Proceedings Of The 4th National Conference On Effectiveness And Efficiency Of The Public Services. Ethiopian Civil Service University.

Firdaus Abdullah (2006) The development of HEdPERF: a new measuring instrument of service quality for the higher education sector, International Journal of Consumer Studies, 30, 6.

Fariba Azizzadeh, Karam Khalili, Iraj Soltani Service Quality Measurement in the Public Sector (2013). International Journal of Economics, Finance and Management. VOL. 2, NO. 1.

Gowan, M., Seymour, J., Ibarreche, S. \& Lackey, C. (2001) "Service Quality In A Public Agency: Same Expectations But Different Perceptions By Employees, Managers, And Customers," Journal Of Quality Management, Vol. 6, P. 275-291.

Iihaamie, (2010). Service Quality In Malaysian Public Service: Some Findings International Journal Of Trade, Economics And Finance, Vol. 1.

Jenet (2011) The Relationship Between Customer Satisfaction And Service Quality: A Study Of Three Service Sectors In Umeåservice Quality And Customer Satisfaction In Public Sector Organization (The Commission On Human Rights And Administrative Justice July 2012).

Leedy Pd \& Ormrod Je. (2005). Practical Research: Planning And Design ( $8^{\text {th }}$ Edition). Upper Saddle River, $\mathrm{Nj}$ : Pearson.

Mohamed Khalifa (2003). Determinants of Satisfaction at Different Adoption Stages of Internet-Based Services

Mesfin Taffesse (2009). The Ethiopian Civil Service Reform Program: In Taye Assefa (Ed.): Digest Of Ethiopia's National Policies, Strategies And Programs. FSS. Addis Ababa.

Nyeck, S., Morales, M., Ladhari, R., \& Pons, F. (2002). 10 YEARS OF SERVICE QUALITY MEASUREMENT: REVIEWING THE USE OF THE SERVQUAL INSTRUMENT. Cuadernos de Difusion, 7(13), 101-107

Parasuraman, A., Zeithaml, Valerie A.\& Berry, Leonard.L. (1985). “A Conceptual Model Of Service Quality And Its Implications For Future Research,” Journal Of Marketing, Vol. 49, P. 41-50.

Parasuraman, A., Zeithaml, V.A. and Berry, L. 1988. SERVQUAL: A multiple-item scale for measuring consumer perceptions of service quality. Journal of Retailing 64 (1): 14-40.

Potluri, Dr. Rajasekhara Mouly; V. S., Mangnale. An Assessment Of Ethiopian Telecom Customer Satisfaction. 
Global Journal of Management And Business Research, [S.1.], v. 10, n. 4, june 2010.

Teicher, J., Hughes, O. \& Dow, N. (2002) "E-government: a new route to public service quality",Managing Service Quality, vol. 12(6), p. 384-93.

Vijayakanth Urs M.C., Harirao A.N., Santhosh Kumar A.N.(2014), "Customer Satisfaction Through Service Quality In Public Service ”, Journal Of Emerging Research In Management \& Technology Issn: 2278-9359 (Volume-3, Issue-5)

Zeithaml, Valerie A. \& Bitner, Mary J. (1996) Services Marketing, Mcgraw-Hill, New York, N.Y Kotzar, H., Seuring, S., Muller, M. And Reiner, G. (2005). Research Methodologies In Supply Chain Management, Yhysica-Verlag, Germany: Heidelberg.

Zeithaml, Valerie A., Berry, Leonard L. \& Parasuraman, A. (1996) "The Behavioral Consequences of Service Quality," Journal Of Marketing, Vol. 60(2), P.31 -46.

Zelalem Teklemariam, Abiyu Mekonnen, Haji Kedir and Getachew Kabew (2013) Clients and clinician satisfaction with laboratory services at selected government hospitals in eastern Ethiopia. BMC Research Notes.

\begin{abstract}
About the Authors
Alemseged Gerezgiher Hailu is an assistant professor of development studies at the Center of Rural Development, College of Development Studies, Addis Ababa University. He has been teaching for more than 12 years in the university. He has conducted several researches in entrepreneurship, small and medium enterprises, food security, local economic development, socio-economic impact assessment, and rural poverty. He is also member of some committees in the university and is associate consultant at the Ethiopian Management Institute.
\end{abstract}

Hailay Gebretsadik Shifare is a Senior Consultant (researcher, trainer and consultant), Ethiopian Management Institute, Addis Ababa, Ethiopia. He has been teaching for more than 10 years in Universities, and currently he is researcher, trainer and consultant in the institution. He has conducted several researches in international business, export performance, transformational leadership, marketing, Human Resource, change tools, Gender mainstreaming, management development. He is also member of Ethiopian Economic Association and member of different committees in the Institution. He is also an author of two books. 